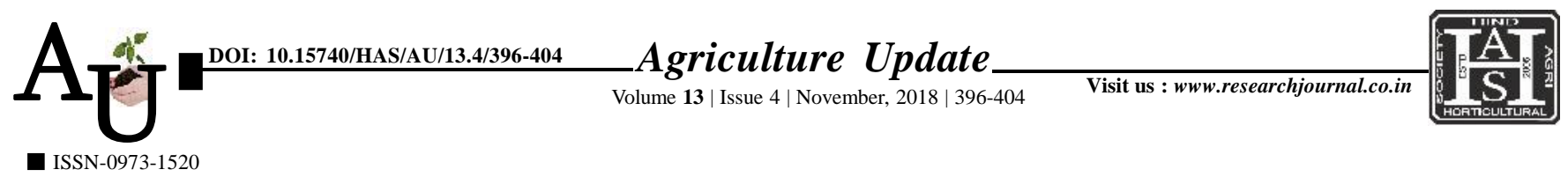

\title{
Research Article: Adoption of improved mandarin production technologies among mandarin growers of Darjeeling hills
}

Article Chronicle:

Received :

21.08.2018;

Revised :

20.09.2018;

Accepted :

05.10 .2018

\section{KeY Words:}

Adoption, Darjeeling Mandarin, Improved production

technologies, Socioeconomic
Author for correspondence :

\section{Rakesh Roy}

Darjeeling Krishi Vigyan

Kendra, Uttar Banga

Krishi Viswavidyalaya,

Kalimpong (W.B.) India

Email:rakeshvetext@

gmail.com

See end of the article for

authors' affiliations
SUMMARY : The study was undertaken with the objective to assess adoption behaviour of improved mandarin production technologies among mandarin orange growers. The study was purposively conducted in the hill region of Darjeeling district in West Bengal where mandarin orange is the pride fruit of the region. In all, 150 respondents were considered for the study and personal interview method was applied for collection of data using semi-structure interview schedule and farm visit. The socioeconomic profile of the mandarin orange growers shows that mean age of the respondents was 50 years with mean education upto class 6 and agriculture as primary occupation. Mean land holding was 2.3 hectares with 15 numbers of plants and having 28 years of farm experience. Annual income from mandarin production was about 0.99 lakhs. Majority of the respondents had no social participation and had training exposure among 20 per cent of the respondents. The study shows that adoption of improved mandarin production technologies was low among the mandarin growers. Total Rank Order Score (TROS) shows that proper harvesting time and methods was highly adopted. St aking and supporting was highly adopted by the respondents. The study shows low adoption of soil treatment, seedling preparation, practices of scientific intercropping. The study also shows low adoption of other improved mandarin production technologies like application of manures, application of micronutrient, water treatment, fruit drop control measures and plant protection measures. The study further shows that age $(p<0.01)$ of the mandarin growers was negatively correlated and education $(p<0.01)$ of the respondents, number of plants $(\mathrm{p}<0.05)$ and training received $(\mathrm{p}<0.05)$ by the respondents was positively correlated with adoption of mandarin production technologies. The study reveals that education of the respondents and the numbers of plants in the orchard were the main contributing factors for adoption of improved mandarin technologies.

How to cite this article : Roy, Rakesh, Kharga, Basu Deo and Moktan, Mendel Wangchuk (2018). Adoption of improved mandarin production technologies among mandarin growers of Darjeeling hills. Agric. Update, 13(4): 396-404; DOI : 10.15740/HAS/AU/13.4/396-404. Copyright@2018: Hind Agri-Horticultural Society. 